Article

\title{
Two New Sphingolipids from the Leaves of Piper betle $\mathrm{L}$.
}

\author{
Duo-Zhi Chen, Hua-Bin Xiong, Kai Tian, Jun-Ming Guo, Xiang-Zhong Huang * \\ and Zhi-Yong Jiang *
}

Key Laboratory of Chemistry in Ethnic Medicinal Resources, State Ethnic Affairs Commission \& Ministry of Education, Yunnan University of Nationalities, Kunming 650500, Yunnan, China

* Authors to whom correspondence should be addressed;

E-Mails: huangxiangzhong@ynni.edu.cn (X.-Z.H.); jiangzy2010@163.com (Z.-Y.J.);

Tel.: +86-871-6591-3013 (X.-Z.H.); Fax: +86-871-6591-0017 (X.-Z.H.).

Received: 14 July 2013; in revised form: 4 September 2013 / Accepted: 5 September 2013 /

Published: 12 September 2013

\begin{abstract}
Two new sphingolipids, pipercerebrosides A (1) and B (2), were isolated from the leaves of Piper betle L. Their structures, including absolute configurations, were determined by spectroscopic analysis and chemical degradation. These two compounds did not show significant cytotoxic activity against the cancer cell lines K562 and HL-60 in a MTT assay.
\end{abstract}

Keywords: Piper betle L.; Piperaceae; sphingolipids; spectroscopic analysis; cytotoxic

\section{Introduction}

The stems and/or leaves of Piper betle L., an evergreen perennial creeper plant widely distributed in the south of China, are used as Chinese Traditional Medicines to cure stomachache, wind-cold cough, sore and furuncle, and eczema [1]. This plant has been known to contain chemical compounds, such as alkaloids, steroids, phenols, and terpenes, with a wide range of bioactivities, like antioxidant, antifungal, antiulcerogenic, antiplatelet, antidiabetic, anti-inflammatory, antifilarial, and antimicrobial activity [2-4].

In a previous study, we extracted $P$. betle stems collected from western China with acetone. This extract, from which eight piper amides and two lignans were isolated, showed antioxidant activity in a 2,2-diphenyl-1-picrylhydrazyl radical (DPPH), scavenging assay and antibacterial activity in a disc diffusion test [5]. Our continuing studies on the leaves of the plant has now led to the isolation of two new sphingolipids, pipercerebrosides A (1) and B (2) and other five known sphingolipids, 3-octadecenamide, 3-eicosenamide, agelasphin-11, agelasphin-7a and agelasphin-13. Sphingolipids have been found to have 
anti-tumor, immunostimulatory, neuritogenic, antiviral, antifungal, and nematicidal activities [6-8]. In this paper we present the isolation and structural elucidation of the new compounds.

\section{Results and Discussion}

\subsection{Structure Analysis of Pipercerebroside A}

Compound 1 was isolated as a white amorphous powder. Its molecular formula was determined to be $\mathrm{C}_{35} \mathrm{H}_{67} \mathrm{NO}_{10}$ by HRESIMS ( $\mathrm{m} / z$ 662.4797 [M + H] $]^{+}$, calcd. for 662.4799). The IR spectrum of 1 showed absorption bands for hydroxyl groups at $3,385 \mathrm{~cm}^{-1}$ and for a secondary amide at $1,653 \mathrm{~cm}^{-1}$. The ${ }^{1} \mathrm{H}$ - and ${ }^{13} \mathrm{C}-\mathrm{NMR}$ (Table 1$)$ spectra of $\mathbf{1}$ indicated the presence of a $\beta$-D-glucopyranosyl moiety $\left(\delta_{\mathrm{H}} 4.14,1 \mathrm{H}\right.$, $\mathrm{d}, J=7.6 \mathrm{~Hz}$, anomeric proton; $\delta_{\mathrm{C}} 103.9,73.9,77.3,70.4,76.9$, and 61.5$)$, an amide linkage $\left(\delta_{\mathrm{H}} 7.55\right.$, $\left.1 \mathrm{H}, \mathrm{d}, J=8.6 \mathrm{~Hz} ; \delta_{\mathrm{C}} 174.3\right)$, two olefinic methines $\left[\delta_{\mathrm{H}} 5.28(1 \mathrm{H}, \mathrm{dt}, J=10.0,5.0 \mathrm{~Hz})\right.$ and $5.35(1 \mathrm{H}, \mathrm{dt}$, $J=10.0,5.0 \mathrm{~Hz}) ; \delta_{\mathrm{C}} 129.5$ and 130.3$]$, an amidomethine $\left(\delta_{\mathrm{H}} 3.97, \delta_{\mathrm{C}} 50.4\right)$, an oxygenated methylene $\left(\delta_{\mathrm{H}} 3.96\right.$ and $\left.3.66 ; \delta_{\mathrm{C}} 69.5\right)$, three oxygenated methines $\left(\delta_{\mathrm{H}} 3.46,3.53\right.$ and $3.81 ; \delta_{\mathrm{C}} 71.1,74.3$ and 71.5$)$, two terminal methyls $\left(\delta_{\mathrm{H}} 0.83,6 \mathrm{H}, \mathrm{t}, J=6.5 \mathrm{~Hz}\right)$ and two long-chain aliphatic moieties appearing as a multiplets $\left(\delta_{\mathrm{H}} 1.20-1.30\right)$. All of the above spectral data revealed that 1 was a glycosphingolipid $[9,10]$.

Table 1. ${ }^{1} \mathrm{H}(500 \mathrm{MHz})$ and ${ }^{13} \mathrm{C}-\mathrm{NMR}(125 \mathrm{MHz})$ data for $\mathbf{1}$ (in DMSO) and 2 (in pyridine- $\left.d_{5}\right)^{a}$.

\begin{tabular}{|c|c|c|c|c|c|}
\hline \multirow{2}{*}{ No. } & \multicolumn{2}{|l|}{1} & \multirow{2}{*}{ No. } & \multicolumn{2}{|l|}{2} \\
\hline & $\delta_{\mathrm{H}}$ & $\delta_{\mathrm{C}}$ & & $\delta_{\mathrm{H}}$ & $\delta_{\mathrm{C}}$ \\
\hline $1 \mathrm{a}$ & $3.66(\mathrm{dd}, 1 \mathrm{H}, 10.5,4.0 \mathrm{~Hz})$ & $69.5 \mathrm{t}$ & $1 \mathrm{a}$ & $4.42(\mathrm{dd}, 1 \mathrm{H}, 10.0,4.5 \mathrm{~Hz})$ & $62.9 \mathrm{t}$ \\
\hline $1 b$ & $3.96(\mathrm{dd}, 1 \mathrm{H}, 10.5,4.0 \mathrm{~Hz})$ & & $1 b$ & $4.50(\mathrm{dd}, 1 \mathrm{H}, 10.0,4.5 \mathrm{~Hz})$ & \\
\hline 2 & $3.97(\mathrm{~m}, 1 \mathrm{H})$ & $50.4 \mathrm{~d}$ & 2 & $5.16(\mathrm{~m}, 1 \mathrm{H})$ & $54.0 \mathrm{~d}$ \\
\hline 3 & $3.53(\mathrm{~m}, 1 \mathrm{H})$ & $74.3 \mathrm{~d}$ & 3 & $4.35(\mathrm{~m}, 1 \mathrm{H})$ & $77.1 \mathrm{~d}$ \\
\hline 4 & $3.46(\mathrm{~m}, 1 \mathrm{H})$ & $71.1 \mathrm{~d}$ & 4 & $4.30(\mathrm{~m}, 1 \mathrm{H})$ & $73.9 \mathrm{~d}$ \\
\hline $5 \mathrm{a}$ & $1.48(\mathrm{~m}, 1 \mathrm{H})$ & $32.1 \mathrm{t}$ & $5 \mathrm{a}$ & $2.02(\mathrm{~m}, 1 \mathrm{H})$ & $34.2 \mathrm{t}$ \\
\hline $5 b$ & $1.90(\mathrm{~m}, 1 \mathrm{H})$ & & $5 b$ & $2.19(\mathrm{~m}, 1 \mathrm{H})$ & \\
\hline 6 & $1.20-1.30(\mathrm{~m}, 2 \mathrm{H})$ & $26.1 \mathrm{t}$ & 6 & $1.96(\mathrm{~m}, 2 \mathrm{H})$ & $27.5 \mathrm{t}$ \\
\hline 7 & $1.97(\mathrm{~m}, 2 \mathrm{H})$ & $27.4 \mathrm{t}$ & $7-9$ & $1.26-1.32(\mathrm{~m}, 6 \mathrm{H})$ & $30.5-30.9 \mathrm{t}$ \\
\hline 8 & $5.35(\mathrm{dt}, 1 \mathrm{H}, 10.0,5.0 \mathrm{~Hz})$ & $130.3 \mathrm{~d}$ & $10 \mathrm{a}$ & $2.05(\mathrm{~m}, 1 \mathrm{H})$ & $34.2 \mathrm{t}$ \\
\hline 9 & $5.28(\mathrm{dt}, 1 \mathrm{H}, 10.0,5.0 \mathrm{~Hz})$ & $129.5 \mathrm{~d}$ & $10 \mathrm{~b}$ & $2.29(\mathrm{~m}, 1 \mathrm{H})$ & \\
\hline 10 & $1.97(\mathrm{~m}, 2 \mathrm{H})$ & $27.2 \mathrm{t}$ & 11 & $5.52(\mathrm{dt}, 1 \mathrm{H}, 15.0,6.0 \mathrm{~Hz})$ & 131.7 \\
\hline $11-14$ & $1.20-1.30(\mathrm{~m}, 8 \mathrm{H})$ & $29.0-29.6 \mathrm{t}$ & 12 & $5.52(\mathrm{dt}, 1 \mathrm{H}, 15.0,6.0 \mathrm{~Hz})$ & 131.6 \\
\hline 15 & $1.20-1.30(\mathrm{~m}, 2 \mathrm{H})$ & $31.8 \mathrm{t}$ & $13 \mathrm{a}$ & $2.03(\mathrm{~m}, 1 \mathrm{H})$ & $33.8 \mathrm{t}$ \\
\hline 16 & $1.20-1.30(\mathrm{~m}, 2 \mathrm{H})$ & $22.6 \mathrm{t}$ & $13 b$ & $2.17(\mathrm{~m}, 1 \mathrm{H})$ & \\
\hline 17 & $0.83(\mathrm{t}, 3 \mathrm{H}, 6.5 \mathrm{~Hz})$ & $14.2 \mathrm{q}$ & $14-20$ & $1.26-1.32(\mathrm{~m}, 14 \mathrm{H})$ & $30.5-30.9 \mathrm{t}$ \\
\hline $\mathrm{NH}$ & $7.55(\mathrm{~d}, 1 \mathrm{H}, 8.6 \mathrm{~Hz})$ & & 21 & $1.26-1.32(\mathrm{~m}, 2 \mathrm{H})$ & $33.0 \mathrm{t}$ \\
\hline $1^{\prime}$ & & $174.3 \mathrm{~s}$ & 22 & $1.26-1.32(\mathrm{~m}, 2 \mathrm{H})$ & $23.8 \mathrm{t}$ \\
\hline $2^{\prime}$ & $3.81(\mathrm{dd}, 1 \mathrm{H}, 7.5,4.0 \mathrm{~Hz})$ & $71.5 \mathrm{~d}$ & 23 & $0.87(\mathrm{t}, 3 \mathrm{H}, 6.5 \mathrm{~Hz})$ & $15.1 \mathrm{q}$ \\
\hline 3'a & $1.48(\mathrm{~m}, 1 \mathrm{H})$ & $34.8 \mathrm{t}$ & $\mathrm{NH}$ & $8.58(\mathrm{~d}, 1 \mathrm{H}, 9.0 \mathrm{~Hz})$ & \\
\hline 3 b & $2.00(\mathrm{~m}, 1 \mathrm{H})$ & & $1^{\prime}$ & & $174.9 \mathrm{~s}$ \\
\hline
\end{tabular}


Table 1. Cont.

\begin{tabular}{|c|c|c|c|c|c|}
\hline \multirow{2}{*}{ No. } & \multicolumn{2}{|l|}{1} & \multirow{2}{*}{ No. } & \multicolumn{2}{|l|}{2} \\
\hline & $\delta_{\mathrm{H}}$ & $\delta_{\mathrm{C}}$ & & $\delta_{\mathrm{H}}$ & $\delta_{\mathrm{C}}$ \\
\hline $4^{\prime}$ & $1.20-1.30(\mathrm{~m}, 2 \mathrm{H})$ & $24.9 \mathrm{t}$ & $2^{\prime}$ & $4.56(\mathrm{dd}, 1 \mathrm{H}, 7.5,4.0 \mathrm{~Hz})$ & $73.7 \mathrm{~d}$ \\
\hline $5^{\prime}-9^{\prime}$ & $1.20-1.30(\mathrm{~m}, 10 \mathrm{H})$ & $29.0-29.6 \mathrm{t}$ & $3^{\prime} \mathrm{a}$ & $2.05(\mathrm{~m}, 1 \mathrm{H})$ & $34.8 \mathrm{t}$ \\
\hline $10^{\prime}$ & $1.20-1.30(\mathrm{~m}, 2 \mathrm{H})$ & $31.8 \mathrm{t}$ & $3^{\prime} \mathrm{b}$ & $2.21(\mathrm{~m}, 1 \mathrm{H})$ & \\
\hline $11^{\prime}$ & $1.20-1.30(\mathrm{~m}, 2 \mathrm{H})$ & $22.6 \mathrm{t}$ & $4^{\prime} \mathrm{a}$ & $1.65(\mathrm{~m}, 1 \mathrm{H})$ & \\
\hline $12^{\prime}$ & $0.83(\mathrm{t}, 3 \mathrm{H}, 6.5 \mathrm{~Hz})$ & $14.2 \mathrm{q}$ & $4^{\prime} \mathrm{b}$ & $1.96(\mathrm{~m}, 1 \mathrm{H})$ & $27.4 \mathrm{t}$ \\
\hline $1^{\prime \prime}$ & $4.14(\mathrm{~d}, 1 \mathrm{H}, 7.6 \mathrm{~Hz})$ & 103.9 & $5^{\prime}-21^{\prime}$ & $1.26-1.32(\mathrm{~m}, 32 \mathrm{H})$ & $30.5-30.9 \mathrm{t}$ \\
\hline $2^{\prime \prime}$ & $2.95(\mathrm{t}, 1 \mathrm{H}, 8.0 \mathrm{~Hz})$ & 73.9 & $22^{\prime}$ & $1.26-1.32(\mathrm{~m}, 2 \mathrm{H})$ & $33.0 \mathrm{t}$ \\
\hline $3^{\prime \prime}$ & $3.13(\mathrm{~m}, 1 \mathrm{H})$ & 77.3 & $23^{\prime}$ & $1.26-1.32(\mathrm{~m}, 2 \mathrm{H})$ & $23.8 \mathrm{t}$ \\
\hline $4^{\prime \prime}$ & $3.02(\mathrm{~m}, 1 \mathrm{H})$ & 70.4 & $24^{\prime}$ & $0.87(\mathrm{t}, 3 \mathrm{H}, 6.5 \mathrm{~Hz})$ & $15.1 \mathrm{q}$ \\
\hline $5^{\prime \prime}$ & $3.10(\mathrm{~m}, 1 \mathrm{H})$ & 76.9 & & & \\
\hline $6^{\prime \prime} \mathrm{a}$ & $3.56(\mathrm{dd}, 1 \mathrm{H}, 12.0,5.0 \mathrm{~Hz})$ & 61.5 & & & \\
\hline $6^{\prime \prime} \mathrm{b}$ & $3.70(\mathrm{~m}, 1 \mathrm{H})$ & & & & \\
\hline
\end{tabular}

${ }^{a}$ Signals were assigned by means of ${ }^{1} \mathrm{H}-{ }^{1} \mathrm{H}$ COSY, HSQC and HMBC.

Analysis of the ${ }^{1} \mathrm{H}-{ }^{1} \mathrm{H}$ COSY, HMQC, and HMBC spectra led to the assignment of proton and carbon signals for $\mathbf{1}$. Methanolysis of $\mathbf{1}$ yielded a fatty acid methyl ester $\mathbf{1 a}$ and a long-chain base $\mathbf{1 b}$ (Scheme 1). Compound 1a was identified as 2-hydroxydodecanoic acid methyl ester $[\alpha]_{\mathrm{D}}^{23}-1.2(c 0.07$, $\mathrm{CHCl}_{3}$ ) by means of $\mathrm{GC} / \mathrm{MS}$ analysis, and the absolute configuration of $\mathrm{C}-2^{\prime}$ was determined to be $R$ from the specific rotation [11]. The phytosphingosine part is thus a $\mathrm{C}_{17}$ aliphatic amino alcohol unit with three hydroxyls, an amino group, and an olefinic bond. The $2 S, 3 S$, and $4 R$ configurations of the ceramide moieties were assigned by comparing the specific rotation $[\alpha]_{\mathrm{D}}^{23}+9.6$ (c 0.11 , pyridine)], ${ }^{1} \mathrm{H}-\mathrm{NMR}$, and ${ }^{13} \mathrm{C}-\mathrm{NMR}$ data of compound $\mathbf{1}$ with those of the known synthetic ceramide $(2 S, 3 S, 4 R)-2-\left[\left(2^{\prime} R\right)-2^{\prime}\right.$-hydroxytetracosanoylamino]-1,3,4-hexadecanetriol [12] and the natural ceramide 1-O- $\beta$-D-glucopyranosyl-(2S,3S,4R,8E)-2-[(2'R)-2'-hydroxybehenoylamino]-8-octadecene-1,3,4-triol [13]. To determine the position of the olefinic bond in the dihydrosphingosine moiety, $\mathrm{KMnO}_{4}$ oxidation [14] was performed on compound $\mathbf{1 b}$ to yield nonanoic acid (1a) (Scheme 1), which was methylated and detected by GC/MS. This indicated the location of the olefinic bond between C-8 and C-9. The $\Delta[8,9]$ olefinic bond was confirmed to have a $(Z)$-configuration as evidenced by the vicinal coupling constants $(J=10.0 \mathrm{~Hz})$, together with the chemical shifts of C-7 $(\delta 27.4)$ and C-10 ( $\delta 27.2)$. Analysis of the ${ }^{1} \mathrm{H}-{ }^{1} \mathrm{H}$ COSY, HMQC, and HMBC spectra led to the assignment of proton and carbon signals for 1. Methanolysis of $\mathbf{1}$ yielded a fatty acid methyl ester $\mathbf{1 a}$ and a long-chain base $\mathbf{1 b}$ (Scheme 1). Compound 1a was identified as 2-hydroxydodecanoic acid methyl ester $[\alpha]_{\mathrm{D}}^{23}-1.2\left(c 0.07, \mathrm{CHCl}_{3}\right)$ by means of GC/MS analysis, and the absolute configuration of $\mathrm{C}-2^{\prime}$ was determined to be $R$ from the specific rotation [11]. The phytosphingosine part is thus a $\mathrm{C}_{17}$ aliphatic amino alcohol unit with three hydroxyls, an amino group, and an olefinic bond. The $2 S, 3 S$, and $4 R$ configurations of the ceramide moieties were assigned by comparing the specific rotation $[\alpha]_{\mathrm{D}}^{23}+9.6(c 0.11$, pyridine $\left.)\right]$, ${ }^{1} \mathrm{H}-\mathrm{NMR}$, and ${ }^{13} \mathrm{C}-\mathrm{NMR}$ data of compound $\mathbf{1}$ with those of the known synthetic ceramide $(2 S, 3 S, 4 R)-2-\left[\left(2^{\prime} R\right)-2^{\prime}\right.$-hydroxytetracosanoylamino]-1,3,4-hexadecanetriol [12] and the natural ceramide 
1-O- $\beta$-D-glucopyranosyl-(2S,3S,4R,8E)-2-[(2'R)-2'-hydroxybehenoylamino]-8-octadecene-1,3,4-triol [13]. To determine the position of the olefinic bond in the dihydrosphingosine moiety, $\mathrm{KMnO}_{4}$ oxidation [14] was performed on compound $\mathbf{1 b}$ to yield nonanoic acid (1a) (Scheme 1), which was methylated and detected by GC/MS. This indicated the location of the olefinic bond between C-8 and C-9. The $\Delta[8,9]$ olefinic bond was confirmed to have a $(Z)$-configuration as evidenced by the vicinal coupling constants $(J=10.0 \mathrm{~Hz})$, together with the chemical shifts of C-7 ( $\delta 27.4)$ and C-10 $(\delta 27.2)$.

Scheme 1. Methanolysis, oxidation and methylation of pipercerebroside A.

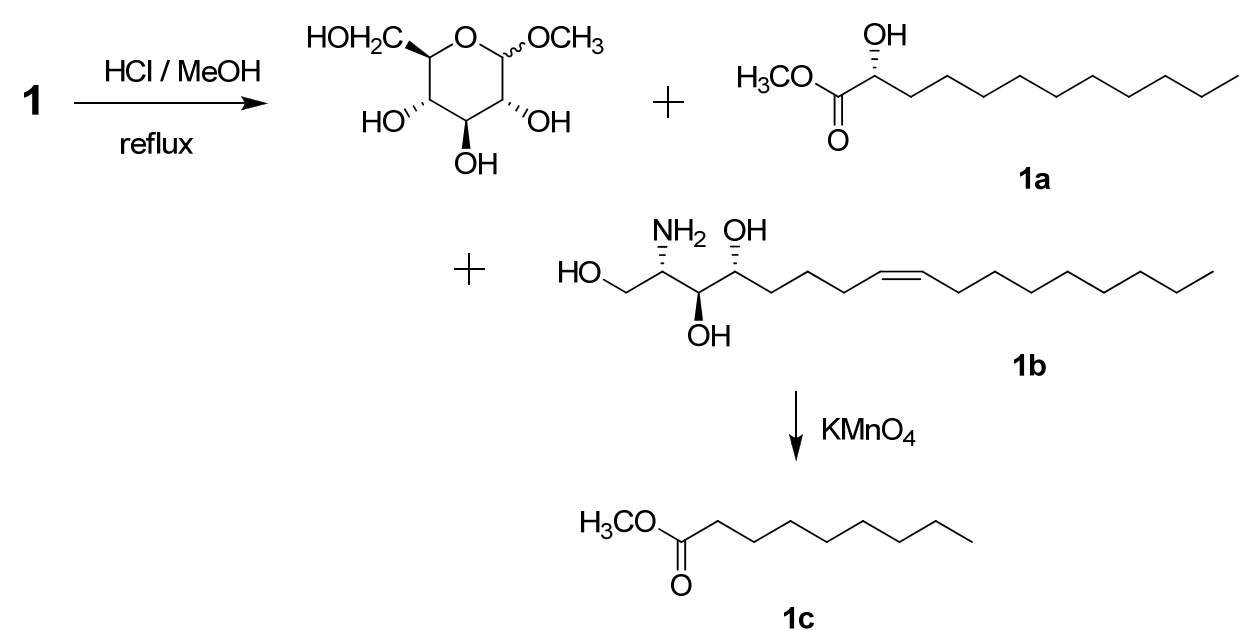

Due to the fact that signals of the carbons adjacent to a $(Z)$-configuration olefinic bond usually appear at $\delta$ 27.0-28.0 [15], whereas those of a $(E)$-configuration olefinic bond normally appear at $\delta 32.0-34.0[9,16]$. Consequently, the structure of 1 was determined to be 1- $O-(\beta$-D-glucopyranosyl)$(2 S, 3 S, 4 R, 8 Z)-2-\{[(2 R)-2$-hydroxyldodecanoyl $]$ amino $\}$ heptadec-8-ene-1,3,4-triol (Figure 1), named pipercerebroside A.

Figure 1. Structures of two new sfingolipids (pipercerebrosides) from the leaves of Piper betle L.
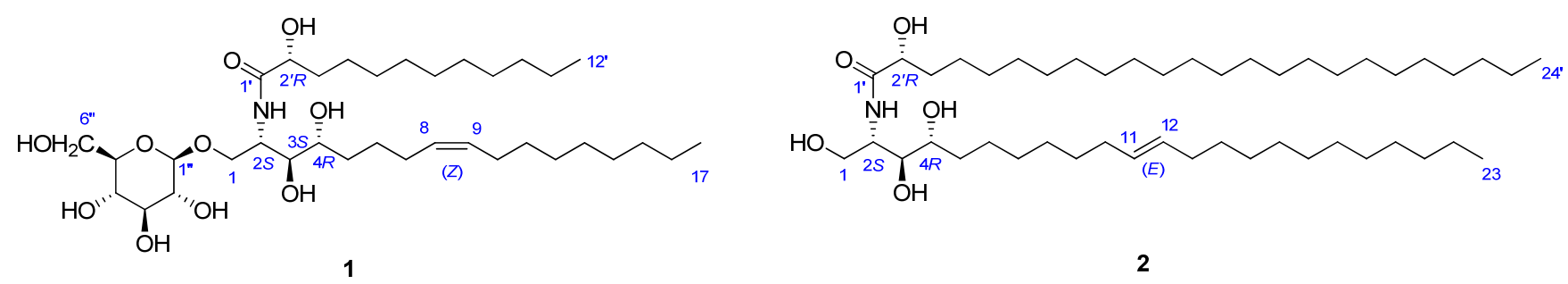

\subsection{Structure Analysis of Pipercerebroside B}

Pipercerebroside $\mathrm{B}$ was isolated as a white amorphous powder. Its molecular formula was determined to be $\mathrm{C}_{46} \mathrm{H}_{91} \mathrm{NO}_{5}$ by HRESIMS $\left(m / z 738.6966[\mathrm{M}+\mathrm{H}]^{+}\right.$, calcd. for 738.6975$)$. The IR spectrum of 2 showed absorption bands for hydroxyl groups at $3,480 \mathrm{~cm}^{-1}$ and for a secondary amide at $1,640 \mathrm{~cm}^{-1}$. The ${ }^{1} \mathrm{H}$ - and ${ }^{13} \mathrm{C}$-NMR (Table 1) spectra of $\mathbf{2}$ indicated the presence of an amide linkage $\left(\delta_{\mathrm{H}} 8.58,1 \mathrm{H}, \mathrm{d}, J=9.0 \mathrm{~Hz} ; \delta_{\mathrm{C}} 174.9\right)$, two olefinic methines $\left[\delta_{\mathrm{H}} 5.52(2 \mathrm{H}, \mathrm{dt}, J=15.0,6.0 \mathrm{~Hz})\right.$; $\delta_{\mathrm{C}} 131.6$ and 131.7], an amidomethine $\left(\delta_{\mathrm{H}} 5.16, \delta_{\mathrm{C}} 54.0\right)$, an oxygenated methylene $\left(\delta_{\mathrm{H}} 4.50\right.$ and 4.42 ; $\left.\delta_{\mathrm{C}} 62.9\right)$, three oxygenated methines $\left(\delta_{\mathrm{H}} 4.30,4.35\right.$ and $4.56 ; \delta_{\mathrm{C}} 73.9,77.1$ and 73.7$)$, and Two terminal 
methyls $\left(\delta_{\mathrm{H}} 0.87,6 \mathrm{H}, \mathrm{t}, J=6.5 \mathrm{~Hz}\right)$ and two long-chain aliphatic moieties appearing as a multiplets $\left(\delta_{\mathrm{H}}\right.$ 1.26-1.32). All of the above spectral data revealed that 2 was also a sphingolipid [17,18]. Analysis of the ${ }^{1} \mathrm{H}-{ }^{1} \mathrm{H}$ COSY, HMQC, and HMBC spectra assigned the proton and carbon signals for 2. Methanolysis of $\mathbf{2}$ yielded a fatty acid methyl ester (FAME) and a long chain base (LCB). The FAME compound was identified as 2-hydroxydodecanoic acid methyl ester by means of GC/MS analysis $\left\{\mathrm{EI}: \mathrm{m} / z\right.$ 398, $\left.\left[[\alpha]_{\mathrm{D}}^{23}-1.4\left(c 0.09, \mathrm{CHCl}_{3}\right)\right]\right\}$ and the absolute configuration of $\mathrm{C}-2^{\prime}$ was determined to be $R$ as in compound 1 . Thus, the LCB part is a $\mathrm{C}_{23}$ aliphatic amino alcohol unit containing three hydroxyls, an amino group and a double bond. The dihydrosphingosine (LCB) moiety was oxidized to yield undecanoic acid, which was methylated and detected by GC/MS. This indicated that the double bond was located at $\mathrm{C}-11$. The 11,12 alkene bond was shown to be trans by the large vicinal coupling constants $(J=15.0)$. The trans geometry of this double bond was also supported by the chemical shift of C-10 ( $\delta 34.2)$ and $\mathrm{C}-13(\delta 33.8)$.

Usually, the signals of the carbons adjacent to a trans double bond appear at $\delta 32-34$, while those of a cis double bond appear at $\delta$ 27-28 [9,16]. Therefore, the structure of $\mathbf{2}$ was determined to be $(2 S, 3 S, 4 R, 11 E)-2-\{[(2 R)-2$-hydroxytetracosanoyl $]$ amino $\}$ tricos-11-ene-1,3,4-triol (Figure 1), named pipercerebroside $\mathrm{B}$.

\subsection{Cytotoxic Activity of Compounds}

The two compounds were evaluated for their cytotoxic activity. None of them showed considerable inhibitory cytotoxic activity against cancer cell lines K562 and HL-60 at the concentration of $10 \mu \mathrm{M}$ in a MTT assay.

\section{Experimental}

\subsection{General}

All reagents were analytical grade and water was distilled twice. TLC was preformed with silica gel GF254 (Marine Chemical Industry Factory, Qingdao, China), and the spots were visualized by spraying with $10 \% \mathrm{H}_{2} \mathrm{SO}_{4} / \mathrm{EtOH}$ reagent. Column chromatography was performed using silica gel (Marine Chemical Industry Factory, Qingdao, China), reverse-phase $\mathrm{C}_{18}$ silica gel (Merck, Darmstadt, Germany) and Sephadex LH-20 (Sigma). Melting points were measured with an X-4 melting point apparatus and are uncorrected. Optical rotations were recorded on a Perkin-Elmer 241 polarimeter. UV spectra were obtained on a Perkin-Elmer Lambda 900 UV/VIS/NIR spectrophotometer. IR spectra were obtained on a Perkin-Elmer 577 spectrometer with KBr pellets.-NMR Spectra were recorded on a Bruker AV 500 spectrometer $\left({ }^{1} \mathrm{H}, 500 \mathrm{MHz} ;{ }^{13} \mathrm{C}, 125 \mathrm{MHz}\right)$, and chemical shifts are presented as values relative to tetramethylsilane as an internal standard. Low-resolution electrospray-ionization mass spectrometry (ESI-MS) and HR-ESI-MS were recorded on a Finnigan LCQ-Advantage mass spectrometer and a VG Auto-Spec-3000 mass spectrometer. Gas chromatography-mass spectrometer (GC-MS) experiments were performed on a Shimadzu GC-17A gas chromatograph apparatus (DB-5 capillary column: $30 \mathrm{~m} \times 0.25 \mathrm{~mm} \times 0.25 \mu \mathrm{m}$, helium flow rate: $0.8 \mathrm{ml} / \mathrm{min}$ ) attached to a Shimadzu GCMS-QP5050A mass spectrometry equipped with an electron impact (EI) ion source 
$(70 \mathrm{eV})$. The column was maintained at $100{ }^{\circ} \mathrm{C}$ for $1 \mathrm{~min}$ and then ramped from 100 to $260{ }^{\circ} \mathrm{C}$ at a rate of $4{ }^{\circ} \mathrm{C} / \mathrm{min}$ with a final hold at $260{ }^{\circ} \mathrm{C}$ for $15 \mathrm{~min}$.

\subsection{Plant Resource}

The leaves of Piper betle were collected from Baoshan city of Yunnan Province in China, in October 2010. It was identified by Prof. Shaobin Ma (Department of Biology, Yunnan University). The stems were harvested and air-dried at room temperature in shade. A voucher specimen (No. 20101020) was deposited in School of Chemistry and Biotechnology, Yunnan University of Nationalities, China.

\subsection{Extraction and Isolation of New Compounds}

The dried leaves $(6.8 \mathrm{~kg})$ of $P$. betle were extracted with $70 \%$ acetone $(40 \mathrm{~L} \times 3)$ under reflux $(4 \mathrm{~h})$. The acetone extract was evaporated to almost dryness in vacuo, and the resulting mixture (760 g) was suspended in water before being successively partitioned with petroleum ether, ethyl acetate, and $n$-butanol $(2 \mathrm{~L} \times 7)$. The ethyl acetate phase was concentrated to produce a black mass $(177 \mathrm{~g})$, which was separated into 11 fractions on a silica gel column using step gradient elution with $\mathrm{CHCl}_{3}-\mathrm{MeOH}$ (1:0-0:1). Fraction 3 (5.2 g) was applied to a Sephadex LH-20 column using MeOH-CHCl 3 (1:2) as a solvent to afford seven subfractions. Subfraction 3-5 (2.7 g) was similarly chromatographed on a Sephadex $\mathrm{LH}-20$ column eluted from $50 \% \mathrm{MeOH}$ in $\mathrm{CHCl}_{3}$ to obtain eight fractions, of which the second fraction $(230 \mathrm{mg})$ was purified by an RP-18 silica gel column eluted with $\mathrm{MeOH}-\mathrm{H}_{2} \mathrm{O}$ (70:30-85:15) to provide compound 1 (28 mg). Subfraction 3-2 (640 mg) was subjected to a silica gel column using $\mathrm{CHCl}_{3}-\mathrm{MeOH}(20: 1)$ as the eluent, yielding compound 2 (13 mg).

\subsection{Methanolysis, Oxidation and Methylation of Pipercerebroside A}

Pipercerebroside A (3 mg) was refluxed with $0.9 \mathrm{~mol} \mathrm{~L}^{-1} \mathrm{HCl}$ in $82 \%$ aqueous $\mathrm{MeOH}(5 \mathrm{~mL})$ for $18 \mathrm{~h}$ [19]. The resulting solution was extracted three times with $n$-hexane. The $n$-hexane solution was washed with water $(5 \mathrm{~mL})$ and dried over anhydrous $\mathrm{Na}_{2} \mathrm{SO}_{4}$ then concentrated to yield compound 1a $(1.1 \mathrm{mg})$. Compound 1a was identified by analysis of GC-MS. After evaporation of $\mathrm{MeOH}$, the $\mathrm{H}_{2} \mathrm{O}$ layer was neutralized with ammonia liquid and extracted with $\mathrm{Et}_{2} \mathrm{O}$. The $\mathrm{Et}_{2} \mathrm{O}$ layer was then dried over anhydrous $\mathrm{Na}_{2} \mathrm{SO}_{4}$ and concentrated to obtain compound $\mathbf{1 b}(0.8 \mathrm{mg})$. 2-Hydroxy-dodecanoic acid methyl ester (1a): colorless oil, $[\alpha]_{\mathrm{D}}^{23}-1.2$ (c 0.07, $\left.\mathrm{CHCl}_{3}\right)$; GC-MS: GC, $t_{\mathrm{R}} 39.41$ min, EI-MS $m / z: 171\left[\mathrm{M}-\mathrm{CH}_{3} \mathrm{OCO}\right]^{+}(39), 127\left[\mathrm{C}_{9} \mathrm{H}_{19}\right]^{+}(6), 111(17), 97(74), 90\left[\mathrm{CH}_{3} \mathrm{OC}(\mathrm{OH})=\mathrm{CH} \mathrm{OH}\right]^{+}(45)$, 83 (72), 69 (89), 55 (91), 43 (100).

Compound $\mathbf{1 b}(0.8 \mathrm{mg})$ was dissolved in $10 \% \mathrm{H}_{2} \mathrm{SO}_{4}$ and acetone (2.0 mL each). $\mathrm{KMnO}_{4}(50 \mathrm{mg})$ was then added to the solution and stirred overnight at room temperature [16,20]. The reaction was then quenched with aqueous $\mathrm{Na}_{2} \mathrm{~S}_{2} \mathrm{O}_{3}(5 \%)$. After removal of acetone, the reaction mixture was extracted with $\mathrm{Et}_{2} \mathrm{O}$. The $\mathrm{Et}_{2} \mathrm{O}$ layer was dried over $\mathrm{Na}_{2} \mathrm{SO}_{4}$ and concentrated to yield the residue, which was methylated using $\mathrm{CH}_{2} \mathrm{~N}_{2}$ in $\mathrm{Et}_{2} \mathrm{O}$ at $0{ }^{\circ} \mathrm{C}$ [20]. The reaction mixture was kept in ice for 30 min before being allowed to stand at room temperature overnight. This procedure resulted in compound 
1c (0.4 mg), which was identified as methyl nonanoate by GC-MS. GC, $t_{\mathrm{R}} 21.30 \mathrm{~min}$, EI-MS m/z: 172 $[\mathrm{M}]^{+}(5), 141\left[\mathrm{M}-\mathrm{OCH}_{3}\right]^{+}(11), 129(9), 87$ (46), 74 (100), 69 (7), 55 (19), 43 (23).

\subsection{Methanolysis, Oxidation and Methylation of Pipercerebroside B}

Pipercerebroside B (3 mg) was treated under the same conditions mentioned above to afford 2-hydroxytetracosanoic acid methyl ester $(0.9 \mathrm{mg})$ and methyl undecanoate (0.3 $\mathrm{mg})$. 2-Hydroxytetracosanoic acid methyl ester: colorless oil, $[\alpha]_{\mathrm{D}}^{23}-1.4$ (c 0.09, $\left.\mathrm{CHCl}_{3}\right)$; GC-MS: GC, $t_{\mathrm{R}} 54.38 \mathrm{~min}, \mathrm{EI}-\mathrm{MS} \mathrm{m} / z: 398[\mathrm{M}]^{+}$(11), 339 [M - $\left.\mathrm{CH}_{3} \mathrm{OCO}\right]^{+}$(9), 281 (5), 207 (10), 145 (4), 127 (6), 111 (12), 97 (27), $90\left[\mathrm{CH}_{3} \mathrm{OC}(\mathrm{OH})=\mathrm{CHOH}\right]^{+}$(28), 83 (27), 57 (58), 44 (100). Methyl undecanoate: GC-MS: GC, $t_{\mathrm{R}} 24.36 \mathrm{~min}, \mathrm{EI}-\mathrm{MS} m / z: 200[\mathrm{M}]^{+}$(4), $169\left[\mathrm{M}-\mathrm{OCH}_{3}\right]^{+}$(5), 157 (4), 143 (7), 101 (6), 87 (47), 74 (100), 69 (8), 55 (16), 43 (22).

\subsection{Spectral data of New Compounds}

Pipercerebroside A: white amorphous powder; mp 191-192 ${ }^{\circ} \mathrm{C} ;[\alpha]_{\mathrm{D}}^{23}+9.6(c 0.11$, pyridine); IR (KBr) $v_{\text {max }}: 3385,3178,2922,2853,1653,1543,1463,1402,1083,932 \mathrm{~cm}^{-1}$; ESI(+)-MS m/z: $662[\mathrm{M}+\mathrm{H}]^{+}$, $684[\mathrm{M}+\mathrm{Na}]^{+}, 500[\mathrm{M}+\mathrm{H}-\mathrm{glu}]^{+} ; \operatorname{HRESI}(+)-\mathrm{MS} m / z: 662.4797[\mathrm{M}+\mathrm{H}]^{+}$(calcd. for $\mathrm{C}_{35} \mathrm{H}_{68} \mathrm{O}_{10} \mathrm{~N}$, 662.4799).

Pipercerebroside B: white amorphous powder; mp 191-192 ${ }^{\circ} \mathrm{C} ;[\alpha]_{\mathrm{D}}^{23}+3.7(c 0.19$, pyridine); IR $\left(\mathrm{CH}_{3} \mathrm{OH}\right) v_{\max }: 3480,2940,2860,1640,1506$, and $1297 \mathrm{~cm}^{-1}$; $\operatorname{ESI}(+)-\mathrm{MS} \mathrm{m} / z: 738[\mathrm{M}+\mathrm{H}]^{+}$; HRESI(+)-MS m/z: $738.6966[\mathrm{M}+\mathrm{H}]^{+}$(calcd. for $\mathrm{C}_{46} \mathrm{H}_{92} \mathrm{NO}_{5}, 738.6975$ ).

\subsection{Bioassay}

Inhibition of cell-growth activity was determined by a MTT assay using human chronic myelogenous leukemia cells (K562) and human promyelocytic leukemia cells [21]. cis-Diamminedichloroplatinum (DDP) was used as a positive control. None of the compounds showed any obvious cytotoxic effect against the cancer cell lines K562 and HL-60.

\section{Conclusions}

Two new sphingolipids, pipercerebrosides A (1) and B (2), were isolated from the leaves of Piper betle. L. Their structures including absolute configurations were determined by spectroscopic analysis 1D-NMR, 2D-NMR and MS experiment and chemical degradation. None of the compounds showed any significant cytotoxic activity against the cancer cell lines K562 and HL-60 at a concentration of $10 \mu \mathrm{M}$ in the MTT assay.

\section{Acknowledgments}

This work was supported by the National Natural Science Foundation of China (NSFC No. 21262047), the Science Foundation of Yunnan Province (No. S2012FZ0227) and the Innovation Team Project of Dai Medicine Research of Yunnan University of Nationalities. We are grateful to 
School of Chemistry and Biotechnology, Yunnan University of Nationalities for measuring-NMR and MS spectra.

\section{Conflicts of Interest}

The authors declare no conflict of interest.

\section{References}

1. Wu, Z.Y. Piper betle. In Flora of China; Science Press: Beijing, China. 1982; Volume 20, pp. $42-45$.

2. Nagori, K.; Singh, M.K.; Alexander, A.; Kumar, T.; Dewangan, D.; Badwaik, H.; Tripathi, D.K. Piper betle L.: A review on its ethnobotany, phytochemistry, pharmacological profile and profiling by new hyphenated technique DART-MS (Direct Analysis in Real Time Mass Spectrometry). J. Pharm. Res. 2011, 4, 2991-2997.

3. Rai, M.P.; Thilakchand, K.R.; Palatty, P.L.; Rao, P.; Rao, S.; Bhat, H.P.; Baliga, M.S. Piper betel Linn (betel vine), the maligned Southeast Asian medicinal plant possesses cancer preventive effects: Time to reconsider the wronged opinion. Asian Pac. J. Cancer Prev. 2011, 12, 2149-2156.

4. Kumar, N.; Misra, P.; Dube, A.; Bhattacharya, S.; Dikshit, M.; Ranade, S. Piper betle Linn. A maligned Pan-Asiatic plant with an array of pharmacological activities and prospects for drug discovery. Curr. Sci. 2010, 99, 922-931.

5. Huang, X.Z.; Yin, Y.; Huang, W.Q.; Sun, K.Z.; Cheng, C.M., Bai, L., Dai, Y. Studies on alkaloids and lignins from stems of Piper betle L. China J. Chin. Mat. Med. 2010, 35, 15-18.

6. Li, H.Y.; Matsunaga, S.; Fusetani, N. Halicylindrosides, antifungal and cytotoxic cerebrosides from the marine sponge Halichondria cylindrata. Tetrahedron 1995, 51, 2273-2280.

7. Natori, T.; Morita, M.; Akimoto, K. Agelasphins, novel antitumor and immunostimulatory cerebrosides from the marine sponge Agelas Mauritianus. Tetrahedron 1994, 50, 2771-2784.

8. Dong, J.Y.; Li, R.; He, H.P.; Zhang, K.Q. Nematicidal sphingolipids from the freshwater fungus Paraniesslia sp.YMF1.01400. Eur. J. Lipid Sci. Technol. 2005,107, 779-785.

9. Jia, A.Q.; Yang, X.; Wang, W.X.; Jia, Y.H. Glycocerebroside bearing a novel long-chain base from Sagina japonica (Caryophyllaceae). Fitoterapia 2010, 81, 540-545.

10. Cateni, F.; Zilic, J.; Falsone, G.; Scialino, G.; Banfi, E. New cerebrosides from Euphorbia peplis L.: Antimicrobial activity evaluation. Bioorg. Med. Chem. Lett. 2003, 13, 4345-4350.

11. Kang, S.S.; Kim, J.S.; Xu, Y.N.; Kim, Y.H. Isolation of a new cerebroside from the root bark of Aralia elata. J. Nat. Prod. 1999, 62, 1059-1060.

12. Sugiyama, S.; Honda, M.; Higuchi, R.; Komori, T. Biologically active glycosides from asteroidea. XXVI. Stereochemistry of the four diastereomers of ceramide and ceramide lactoside. Liebigs Ann. Chem. 1991, 4, 349-356.

13. Ling, T.; Xia, T.; Wan, X.; Li, D.; Wei, X. Cerebrosides from the roots of Serratula chinensis. Molecules 2006, 11, 677-683.

14. Lourenco, A.; Lobo, A.M.; Rodriguez, B.; Jimeno, M.-L. Ceramides from the fungus Phellinus pini. Phytochemistry 1996, 43, 617-620.

15. Liu, H.; Orjala, J.; Rali, T.; Sticher, O. Glycosides from Stenochlaena palustris. Phytochemistry 1998, 49, 2403-2408. 
16. Huang, X.Z.; Yin, Y.; Dai, J.H.; Liang, H.; Dai, Y.; Bai, L. Two new ceramides from the stems of Piper betle L. Chin. Chem. Lett. 2010, 21, 433-436.

17. Yang, N.-Y.; Ren, D.-C.; Duan, J.-A.; Xu, X.-H.; Xie, N.; Tian, L.-J. Ceramides and cerebrosides from Ligusticum chuanxiong HORT. Helv. Chim. Acta 2009, 92, 291-297.

18. Oueslati, M.H.; Mighri, Z.; Jannet, H.B.; Abreu, P.M. New ceramides from Rantherium suaveolens. Lipids 2005, 40, 1075-1079.

19. Kang, S.S.; Kim, J.S.; Son, K.H.; Kim, H.P.; Chang, H.W. Cyclooxygenase-2 inhibitory cerebrosides from phytolaccae radix. Chem. Pharm. Bull. 2001, 49, 321-323.

20. Huang, X.Z.; Wang, Y.H.; Yu, S.S.; Fu, G.M.; Hu, Y.C.; Liu, Y.; Fan, L.H. Iridoid glycosides and grayanane diterpenoids from the roots of Craibiodendron henryi. J. Nat. Prod. 2005, 68, 1646-1650.

21. Fu, G.M.; Wang, Y.H.; Gao, S.; Tang, M.J.; Yu, S.S. Five new cytotoxic triterpenoid saponins from the roots of Symplocos chinensis. Planta Med. 2005, 71, 666-672.

Sample Availability: Samples of the compounds $\mathbf{1}$ and $\mathbf{2}$ are available from the authors.

(C) 2013 by the authors; licensee MDPI, Basel, Switzerland. This article is an open access article distributed under the terms and conditions of the Creative Commons Attribution license (http://creativecommons.org/licenses/by/3.0/). 